\title{
Mercury Islands and their role in understanding seabird island restoration
}

\author{
David R. Towns ${ }^{1,2, *}$, Stephanie B. Borrelle ${ }^{2}$, Joshua Thoresen ${ }^{2}$, Rachel T. Buxton ${ }^{3}$ and \\ Annette Evans ${ }^{4}$ \\ ${ }^{1}$ Science and Policy Group, Department of Conservation, Private Bag 68 908, Newton, Auckland 1145, New Zealand \\ ${ }^{2}$ Institute for Applied Ecology, Auckland University of Technology, Auckland 1142, New Zealand \\ ${ }^{3}$ Department of Zoology and Centre for Sustainability: Agriculture, Food, Energy, Environment, University of Otago, \\ Dunedin 9054, New Zealand \\ ${ }^{4}$ School of Biological Sciences, University of Auckland, Private Bag 92019, Auckland 1142, New Zealand \\ *Author for correspondence (Email:dtowns@doc.govt.nz)
}

Published online: 12 January 2016

\begin{abstract}
The progressive removal of invasive mammals from the Mercury Islands has led to over 25 years of field study designed to test the processes of restoration and natural recovery of these seabird-driven island ecosystems. Resulting from this work, four key restoration questions can now be identified as fundamental to designing island restoration programmes. The questions are: what is the regional context of the island (biogeography); how does each island ecosystem operate (ecosystem function); how have invasive species changed the ecosystem (response effects); and how can progress towards a restoration goal be defined (outcome measures)? Examples of how these questions influenced restoration in the Mercury Islands are provided with Korapuki Island as a case study. However, unpredicted and subtle responses can eventuate. In the Mercury Islands these included a hitherto unknown honeydew parasite-bird-gecko food web and subtle effects of rats on plant regeneration. Promising outcome measures of restoration progress are now being developed, including indices of marine influence using stable isotopes of nitrogen and the use of network analysis to analyse the composition of invertebrate food webs.
\end{abstract}

Keywords: biogeography; species area; colonisation; ecosystem function; eradication; reference sites; Korapuki Island; unknown consequences; New Zealand

\section{Introduction}

Islands are not only repositories of disproportionately high numbers of endemic species (e.g. Keitt et al. 2011; Tershy et al. 2015), they have frequently become refugia against the spread of invasive species and habitat loss (Daugherty et al. 1990). For example, although New Zealand has the world's largest number of endemic species of seabirds, the country also has the largest number of threatened seabirds, with most species now confined to offshore islands following the spread of invasive species (Croxall et al. 2012). Only 20 years ago, Duffy (1994) lamented that island ecosystems were becoming so modified, most were unrecognisable. Selected invasive mammals have periodically been eradicated from islands for about 100 years (Bellingham et al. 2010a). However, the eradication of the most pervasive group, introduced rodents (Atkinson 1985; Towns et al. 2011), only became effective and widely applied at the time Duffy was despairing for the future. Today, rodent eradications have been attempted globally on at least 500 islands (Russell \& Holmes 2015), with the largest number for a single country conducted in New Zealand (Howald et al. 2007; Keitt et al. 2011). The frequency of eradications in New Zealand began to rapidly increase between 1980 and 1990 (Towns et al. 2013), meaning that the potential to learn from the responses of island ecosystems to comprehensive pest removal covers only 30 years. Attempts to restore islands following eradications of rodents have an even shorter history. Here we review 28 years of restoration activity in the Mercury Islands off northeastern New Zealand. Work in the Mercury Islands developed out of two questions posed in the mid-1980s: can rats be eradicated systematically from islands (Towns 1988), and if they can, is it possible to restore entire ecosystems previously modified by introduced mammals (e.g. Towns et al. 1990; Towns \& Atkinson 1991; Towns et al. 1997)?

The developmental history of eradication technology in the context of the Mercury Islands (Towns \& Broome 2003) and a summary of achievements that have stemmed from these activities have already been reviewed (Bellingham et al. 2010a; Towns et al. 2013). Instead, we focus on the question of whether entire ecosystems can be restored, since this is often the goal of invasive species eradications (Towns et al. 1990); a goal that may be particularly challenging for island ecosystems penetrated by invasive species (Norton 2009). The first of the Mercury Islands to be cleared of all invasive mammals was Korapuki (Towns \& Broome 2003) and an ecological restoration plan for the island was completed 10 years ago (Towns \& Atkinson 2004). Here we examine how implementing the Korapuki plan has contributed to the conceptual understanding of island restoration. We aim in particular to address a problem for seabird island ecosystems raised by Duffy (1994): "We cannot put the Humpty Dumpty of an ecosystem back together because we don't know what the original Humpty looked like, nor do we have all the pieces."

This review aims to address the technical issues raised through Duffy's "Humpty Dumpty" problem by using restoration of seabird island ecosystems in the Mercury Islands as a working example. We focus on four key subsidiary questions that are fundamental to understanding the composition and function of island ecosystems: 1) what is the regional context of the island (biogeography); 2) how does each island ecosystem operate (ecosystem function); 
3) how did invasive species change the ecosystem and what effects will their eradication have (response effects); and 4) how can progress towards a restoration goal be defined (outcome measures)? The first two questions help to provide the context within which restoration targets can be set, whereas the second two address the progression of an island towards a target and are more site-based. We demonstrate the relevance of context and site-based approaches by using Korapuki Island as a case study.

\section{Biogeography}

\section{Study area}

The seven Mercury Islands (36.62S; 175.86E) form the largest of four archipelagos from which mammals have been eradicated in their namesake Mercury Islands Ecological District (MIED). The MIED is a biogeographic grouping based on shared geological and biological characteristics (McEwen $1987)$ and extends from Cuvier Island $(36.43 \mathrm{~S} ; 175.77 \mathrm{E})$ in the north through to the Aldermen Islands (36.97S; 176.08E) in the south. Cuvier, all Mercury Islands except Great Mercury and the Aldermen are classed as Nature Reserves under the Reserves Act 1977. These are the most highly protected reserves under New Zealand legislation, with access by permit only. Across the MIED, the range of invasive mammals present has included (Atkinson \& Taylor 1992): goats (Capra hircus), cats (Felis catus), ship rats (Rattus rattus) and kiore ( $R$. exulans) on Great Mercury; goats, cats and kiore on Cuvier; rabbits (Oryctolagus cuniculus), kiore and mice (Mus musculus) on Ohinau; rabbits and kiore on Stanley and Korapuki; and kiore alone on Double, Red Mercury, and Middle Chain (Supplementary Data). Like most offshore islands, all of the islands in MIED have at some time been modified through burning (Atkinson 2004; Bellingham et al. 2010a).
Two biogeographic concepts discussed below assist with understanding how history influences the way we view restoration of the islands in this district.

\section{Vicariance}

The biotic composition of islands in the MIED is largely a function of island origin (e.g. Towns 1994, 2002b; Towns et al. 1997), notably isolation due to sea level rise following the last glaciations (e.g. Hayward 1986). Oceanic islands far from the main islands of New Zealand, such as the Kermadecs (30.37S; $178.48 \mathrm{~W})$, were never connected to larger land masses and are colonised by chance, resulting in genetic drift and high levels of endemism of those species that survive (e.g. Carlquist 1965).

In contrast, islands such as those in MIED are within $20 \mathrm{~km}$ of the coast (i.e. on the continental shelf) of New Zealand and were part of the mainland during the last glaciation. As sea levels rose, the newly formed islands contained gradually constrained subsets of mainland terrestrial communities. Populations in these subsets were derived from genetically diverse gene pools, so drift was much less likely and thus endemism is relatively uncommon. Furthermore, these islands support many terrestrial species unable to disperse over water, including a great diversity of flightless invertebrates as well as terrestrial reptiles (Daugherty et al. 1990). Bathymetric analyses within MIED indicate that by about 8000 years ago, Cuvier and the Aldermen had already been separated from the mainland for at least 4000 years, but the Mercury and Ohinau Islands had only recently lost their dry land connection to the peninsula (Figure 1). At that point, the Mercury archipelago had not formed, but was an extended "Great Mercury super-island". The concept of vicariance applies here: present disjunctive distributions reflecting the fragmentation of contiguous populations by rising sea levels as a geographic barrier (Wiley 1988). Thus, species today confined to individual islands likely once inhabited the whole Great Mercury super-island.

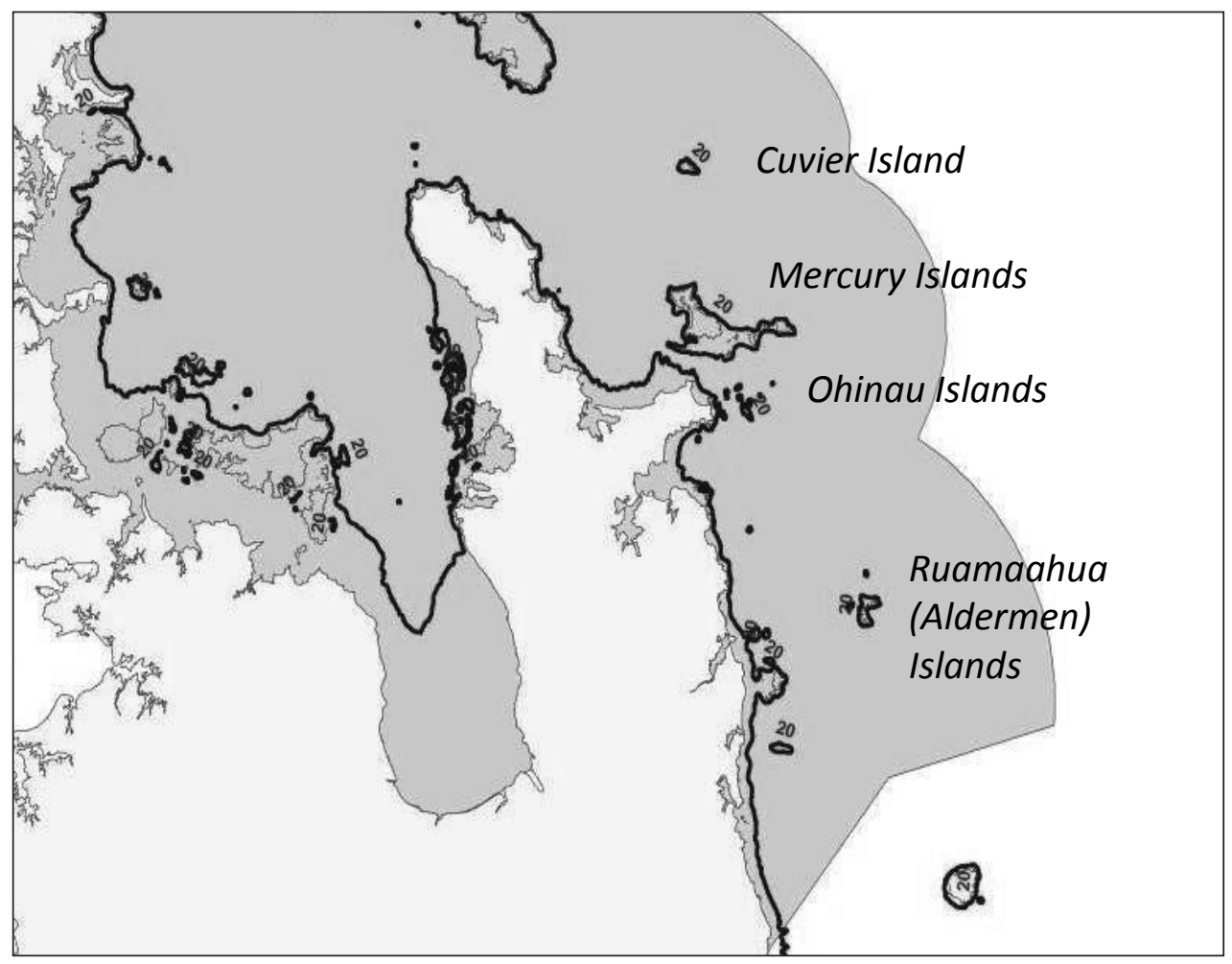

Figure 1. Coastlines around the Coromandel Peninsula at about 8000 years ago based on the 20 $\mathrm{m}$ isobaths (shaded areas are sites within Hauraki Gulf Marine Park) showing four main archipelagos in Mercury Islands Ecological District. 
Past connections to the mainland and inclusion within the same ecological district might imply wide application of a variance model. However, the relationship between biota of the Mercury archipelago and others in MIED is not particularly clear. For example, two species of skinks, Oligosoma whitakeri and O. alani, are present on mammal-free islands in the Mercury Islands but absent from mammal-free islands in the Aldermen. However, a related species, O. oliveri is present in both archipelagos (Pickard \& Towns 1988). Likewise, the tusked wēta (Motuweta isolata), although present in the Mercury Islands, is absent from mammal-free islands in the Aldermen. Subtle differences such as these may reflect differences in isolation history. These differences suggest that for poorly dispersed groups such as flightless invertebrates and reptiles, there has been less unity of distribution than is implied by the vicariance model. Consequently, if high ecological integrity is the restoration goal (see below), the most defensible approach may be to focus within archipelagos; acknowledging that the greatest risk of errors for assumptions about community composition would likely arise from extrapolations between them.

\section{Species-area relationships}

A fundamental principle of island biogeography is that, aside from some exceptions, the number of species usually increases in proportion to area (McArthur \& Wilson 1967). For example, Whitaker (1978) used this relationship to predict the expected species diversity of reptiles on islands with and without introduced rodents. Although the species-area relationship holds for islands without invasive mammals (e.g. Borrelle et al. 2015), the reverse can develop on islands with invasive vertebrates. As a result, the smallest Mercury Islands, which have not been invaded by mammals, now have more reptile species than larger ones invaded by kiore and rabbits. A similar relationship in response to predation pressure is likely to hold for the large flightless invertebrates.

Species-area relationships are useful because they provide an empirical measure of the proportional reduction of assemblages in the presence of introduced mammals, as well as a basis for predicting the composition of restored assemblages. For example, islands with invasive mammals in the MIED had a $50 \%$ reduction in reptile fauna and $75 \%$ reduction in wēta fauna (e.g. Towns et al. 1997), which thereby suggests the level of species restoration required for each group.

\section{Ecosystem function}

Without detailed understanding of how island ecosystems function when invasive species are absent, it may be difficult to determine how restoration efforts should proceed on islands where invasive species have been present. This understanding can be greatly assisted through the use of reference sites (White \& Walker 1997), which are model sites or islands used in order to predict the trajectory or endpoint of an impaired ecosystem after restoration interventions (e.g. Balaguer et al. 2014). Although such sites help with understanding ecosystem function, they do not necessarily indicate the capacity for natural dispersal into previously modified sites. As we discuss below, dispersal ability of some species (particularly plants) often relies on a vertebrate dispersal agent.

\section{Reference sites}

Within the MIED, six small islands (3-30 ha) that have never been invaded by introduced mammals can be used as reference sites for restoration of the eight islands (18-1872 ha) from which invasive species have been or are being removed. Five of these reference islands have high seabird abundance and extreme surface fragility due to burrowing by birds. On the larger reference islands ( $>2 \mathrm{ha}$ ), in addition to seabirds, there are dense and diverse reptile populations and numerous species of flightless invertebrates, including wēta, gastropods and spiders (Towns et al. 2009; Bellingham et al. 2010a). These sites indicate the structure and function of seabird driven island ecosystems of different sizes before mammalian predator invasion in the MIED.

Additional reference information can be obtained from invaded islands larger than the uninvaded reference sites. Given their greater area, such islands can have a higher species diversity of plants, which is helpful in identifying species particularly sensitive to browsing (see below). Such sites may only provide fragmentary information, but they extend information available about the composition of local communities as part of an "ecological memory" (sensu Balaguer et al. 2014).

\section{Recolonisation potential}

When introduced species are removed, many species can return and recover unaided. This recovery is particularly likely for most species of plants, as long as dispersal mechanisms are available and/or local populations remain. For many plants, dispersal is through birds such as kererū or fruit pigeons (Hemiphaga novaeseelandiae), which on these islands are the only species capable of long distance seed dispersal of plants with large fruit including kohekohe (Dysoxylum spectabile), taraire (Beilschmedia tarairi) and tawāpou (Pouteria costata; Table 1). Other forms of distribution are less conventional. For example, the seed pods of Pisonia are extremely adhesive, potentially as a means of spread between locations by relatively large seabirds, which would explain the wide distribution of the genus throughout the Pacific (e.g. Burger 2005). Given that most islands in the MIED are now free of introduced mammals, it may be possible for natural dispersal through wind and birds to facilitate dispersal of plants.

Despite impressive flight mobility, seabirds still face some barriers to natural dispersal. Studies of seabird colonies have often indicated high philopatry, with birds behaviourally tied to their original birthplace (Warham 1996). A review of colonisation ability of seabirds around New Zealand found more capacity to colonise new islands than had previously been assumed (Buxton et al. 2014). However, frequency of colonisation declined rapidly with distance from source islands, and natural colonisation by most species became unlikely when source populations were $>25 \mathrm{~km}$ away. Ellipses based on the $25 \mathrm{~km}$ radius around uninvaded, densely populated islands in MIED indicate that Mercury, Ohinau and Aldermen archipelagos are all within a $20 \mathrm{~km}$ radius (Figure 2). However, Cuvier is between 20 and $25 \mathrm{~km}$ from the nearest large uninvaded islands, and still has only been recolonised naturally by three species of Procellariiformes: grey-faced petrel (Pterodroma macoptera), fluttering shearwater (Puffinus gavia) and diving petrel (Pelecanoides urinatrix) (Borrelle et al. 2015). 
Table 1. Native species of plants suppressed by kiore as determined from responses of resident species to rodent eradications (from Atkinson 1964; Towns et al. 1997; Campbell \& Atkinson 1999, 2002), with canopy species marked*

\begin{tabular}{|c|c|c|}
\hline Species & Study site (s) & Status on reference sites \\
\hline Kohekohe Dysoxylum spectabile* & Double, Cuvier, Red Mercury & $\begin{array}{l}\text { Locally dominant canopy species on larger islands, rare on } \\
\text { Middle, unknown from Green }\end{array}$ \\
\hline Parapara Pisonia brunoniana & Cuvier, Double, Middle Chain & $\begin{array}{l}\text { Subcanopy species capable of forming dense thickets but } \\
\text { absent from Middle and Green }\end{array}$ \\
\hline Karo Pittosporum crassifolium & $\begin{array}{l}\text { Double, Red Mercury, } \\
\text { Middle Chain }\end{array}$ & $\begin{array}{l}\text { Widespread and common small tree in coastal areas on Middle } \\
\text { and Green }\end{array}$ \\
\hline Tawapou Pouteria costata* & $\begin{array}{l}\text { Double, Red Mercury, } \\
\text { Middle Chain }\end{array}$ & $\begin{array}{l}\text { Often scattered on larger islands but rare on smaller seabird } \\
\text { islands such as Middle }\end{array}$ \\
\hline Karamu Coprosma macrocarpa & Double, Red Mercury & $\begin{array}{l}\text { Widespread and common small tree; now widespread on most } \\
\text { islands }\end{array}$ \\
\hline Taupata C. repens & Red Mercury & Coastal shrub now common in coastal areas on all islands \\
\hline Coastal maire Nestigis apetala* & Cuvier & Coastal tree absent from Mercury Islands \\
\hline Nikau Rhopalostylus sapida & Cuvier & $\begin{array}{l}\text { Palm, which can be locally abundant but absent from Mercury } \\
\text { Islands }\end{array}$ \\
\hline Houpara Pseudopanax lessonii & Double, Cuvier, Middle Chain & Shrub or small tree widespread on Mercury Islands \\
\hline Milktree Streblus banksii* & Middle Chain & $\begin{array}{l}\text { Small tree with extensive areas as canopy on Middle Island and } \\
\text { spreading on Stanley }\end{array}$ \\
\hline $\begin{array}{l}\text { Hymenanthera Melicytus } \\
\text { novae-zelandiae }\end{array}$ & Red Mercury & Shrub widespread in coastal areas on Middle \\
\hline
\end{tabular}

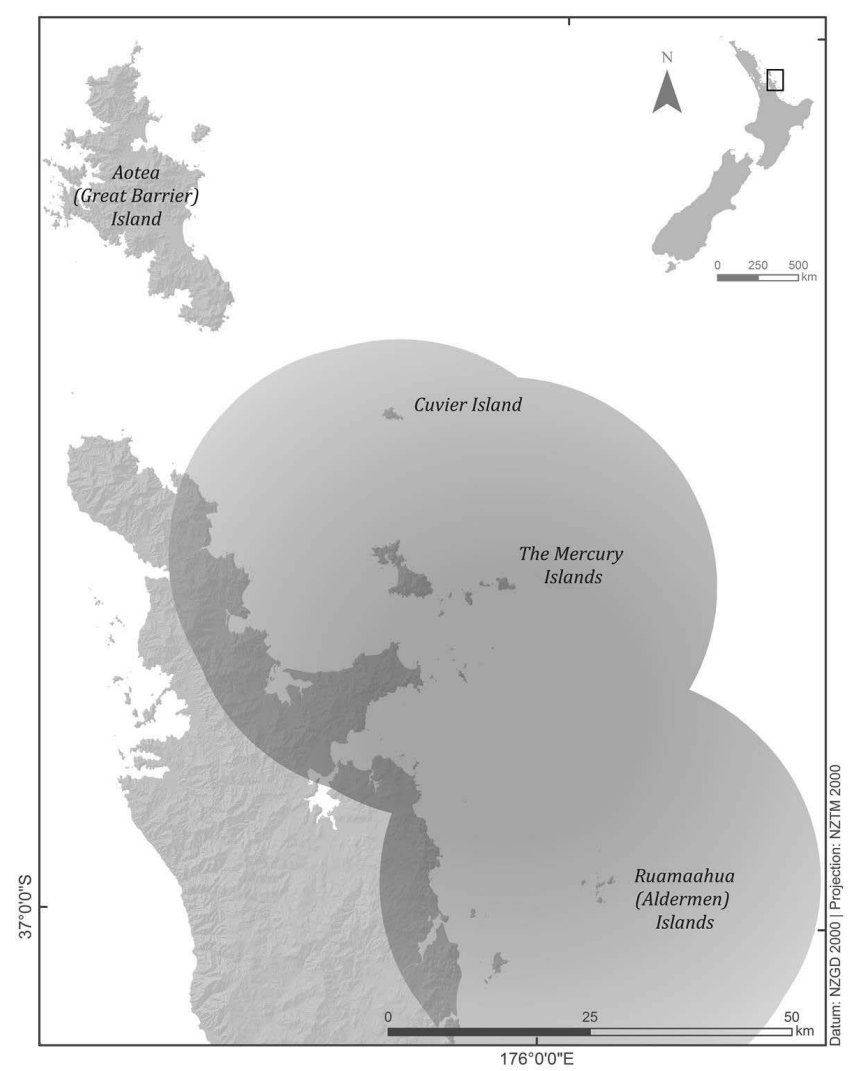

Figure 2. Potential seabird recolonisation ellipses based on 25 $\mathrm{km}$ ranges from uninvaded source islands within the Mercury Islands Ecological District.

\section{Effects of invasive species on ecosystem function}

Occasionally the effects of invasion are so extreme they are even visible to offshore observers. Examples include extensive vegetation modification and soil loss following decades of browsing by goats (Capra hircus) or rabbits (e.g. Merton 1987; Bellingham et al.2010b). More often the effects are subtle, but even when the invasive species are rodents (e.g. Towns et al. 2006) or ants (e.g. O'Dowd et al. 2003), they can still produce catastrophic changes to ecosystem function.

Studies in New Zealand of the distribution of tuatara (Sphenodon punctatus), lizards, invertebrates and plants compared with kiore over a large sample of islands indicate that some species populations are either heavily suppressed by these rats or incompatible with them (Whitaker 1978; Watt 1986; Atkinson 1986; Campbell \& Atkinson 1999). A similar comparative approach was used to determine the effects of suppressed seabird populations on island ecosystem function. Nine islands in northern New Zealand (including four in the MIED) with large populations of burrowing seabirds were compared with nine where seabirds were suppressed by introduced rats. On islands with few seabirds, soils had $47 \%$ less total C, 45\% less total N, 53\% less total P and 23\% lower marine-derived $\delta^{15} \mathrm{~N}$ than on uninvaded islands (Fukami et al. 2006). Furthermore, on islands with few seabirds, 11 orders of leaf-litter and soil-inhabiting invertebrates were less abundant, foliar and litter $\mathrm{N}$ concentrations in several plant species were lower, and litter decomposition rates were slower than on uninvaded islands with large seabird colonies (Towns et al. 2009; Wardle et al. 2009). These studies demonstrate the diverse and subtle effects of seabirds on island ecosystems, and conversely, the extent to which the systems can change when mammalian predators invade. Such studies do not demonstrate cause and effect between mammal invasion and shifts in ecosystem function. They do however, provide a powerful basis for developing hypotheses and conceptual models, which can then be tested experimentally (Veltman 1996; Towns et al. 2009). 
Three inferences relevant to islands restoration stem from the above observations. First, introduced species likely have direct negative effects on resident species assemblages. Decades after eradication, the legacy of some invasive mammals, such as kiore, remain on islands, as has been demonstrated by the absence of selected species of seabirds, plants, invertebrates and lizards (Towns 2009). Second, through activities such as burrowing and defecation, seabirds are likely to be one of the most powerful biotic drivers of islands ecosystems around New Zealand (Mulder \& Keall 2001) and elsewhere (Mulder et al. 2011). Finally, when invasive species suppress seabird abundance, ecosystem functions engineered by seabirds are suppressed, resulting in a wide range of indirect effects (e.g. Towns \& Atkinson 2004; Russell 2011).

\section{Effects of eradicating invasive species}

Four sources of information can help us predict the response of native species and ecosystems to the removal of invasive species from islands: 1) studies of the responses of plants and animals after eradication; 2) the use of reference sites that lack invasive species as defined above; 3) using chronosequences of islands from which invasive species have been removed (e.g. Buxton et al.2016); and 4) paleoecological studies of plant and animal remains in middens, caves, sand-dunes and wetlands (e.g. Towns \& Ballantine 1993; Wilmshurst et al. 2014). Direct response studies are most valuable on those islands where a single invasive species was introduced then removed, which avoids complications caused by interactions between invasive species (Towns 2011). An example is provided by tuatara, a species which managed to co-exist with kiore on several islands. In MIED, tuatara were reduced to such low numbers $(<20)$ on kiore invaded islands, their responses to eradication were un-measureable over short timeframes. However, larger numbers of tuatara survived in the presence of kiore in the Marotere Islands, where despite variation between islands, comparisons of recruitment rates of juvenile tuatara before and after kiore eradication demonstrated significant demographic shifts in tuatara populations. Potential competitive effects between kiore and adult tuatara were also revealed by changes in body condition (Towns et al. 2007). Similar comparisons between islands in MIED, using uninvaded islands and those still with kiore, indicated that kiore suppressed 11 of the 17 species of plants studied (Table 1) and that forest composition on the invaded islands had likely been significantly altered (Campbell \& Atkinson 2002).

Some apparently extirpated species have reappeared many years after eradications on islands were completed. For example, five populations of geckos and four populations of skinks have reappeared on islands around New Zealand cleared of invasive mammals. One species of gecko, Dactylocnemis pacificus, reappeared on at least two the Marotere Islands less than 10 years after the removal of kiore, but the same species has still not been found on any of the Mercury Island Nature Reserves previously inhabited by invasive mammals despite $>20$ years of monitoring (D. Towns unpublished data).

\section{Restoration goals}

All restoration projects require a goal or target (Atkinson 1988). This in itself can be problematic if there is little clarity about what the system previously looked like (Duffy 1994) and since reference sites usually change with time (Simberloff 1990). There are two approaches to defining restoration goals: time or function. A goal could be based on a previous time, such as before the arrival of invasive species, which requires the identification of historic benchmarks (e.g. Atkinson 1988). An alternative is to use ecosystem function as a goal, which does not require the historic reference point, but does require understanding of how key components of ecosystems interact. Such an approach is also greatly assisted if reference sites are available. Now that there is considerable evidence about the engineering role of seabirds (e.g. Mulder et al. 2011), seabird driven island ecosystems as a goal would be a logical option for many islands. This then raises the question of whether intervention is needed.

If the goal is to restore seabird-driven ecosystems, three pieces of evidence suggest that no further manipulation may be required after eradication at many locations (Buxton 2014). First, Jones (2010) analysed marine-derived nitrogen $\left(\delta^{13} \mathrm{~N}\right)$ in soils, plants and spiders (as predatory invertebrates) across islands at different stages of recovery after eradication of mammals. She found increasing evidence of a marine seabirdderived signature with time since mammal eradication and predicted that ecosystems with seabird-driven attributes can recover in a few decades. Second, Buxton et al. (2014) found that the rate of seabird recovery on some islands is higher than might be predicted from the breeding success of residents. They found evidence that existing burrowing seabird colonies attract immigrants, which can be conspecifics, but may also be other species. Finally, where suitable habitat is available, and the density of potential source colonies is sufficient, sites can be identified where natural recovery is most likely (Buxton 2014). In MIED, natural seabird recolonisation potential is high in all archipelagos except Cuvier (Figure 2) (Borrelle et al. 2015).

Given that introduced mammals can extirpate a range of species from within these systems (Table 2), a second option is to extend the functional goal of seabird driven ecosystems to include reintroducing species unable to naturally recolonise. For example, since the above biogeographic analyses support an argument for vicariance within the Mercury islands, restoration could aim to restore seabird-driven ecosystems with community composition typical of the Mercury Islands archipelago. The case study outlined below acknowledges the capacity for natural recovery of seabird populations but also the inability of some species of reptile and invertebrate to re-colonize. For other species, such as the tree wēta (Hemideina thoracica) and some species of plants, an overlay of data from reference sites combined with knowledge of the effects of invasive species within the archipelago informed the extended restoration goal.

\section{When is the restoration process complete?}

The question of when a restoration project has reached a predefined target is of particular interest to conservation managers. The range of unpredictable outcomes and uncertainties involved with island restoration are so numerous that predicting an endpoint for such an exercise is complex and could involve timescales beyond the life span of a researcher. For example, the time to reach carrying capacity for Whitaker's skinks (Oligosoma whitakeri) reintroduced to Korapuki Island was estimated as at least 140 years (Miller 2009). On other islands in the archipelago, such as Red Mercury Island, which is over ten times larger than Korapuki, the recovery of reintroduced populations of the same species will inevitably take even longer.

The criteria for successful restoration through 
Table 2. Status of species of flightless invertebrates and reptiles present on mammal-free Mercury islands but absent from Korapuki Island before removal of introduced mammals and identified as candidates for reintroduction by Towns \& Atkinson (2004)

\begin{tabular}{llll}
\hline Name & Ecological role & Reintroduction status & Tolerance of invasive predators \\
\hline $\begin{array}{l}\text { Gastropoda } \\
\text { Rhytida greenwoodi }\end{array}$ & $\begin{array}{l}\text { Predator of gastropods and } \\
\text { earthworms }\end{array}$ & $\begin{array}{l}\text { Still to be reintroduced; } \\
\text { known only from Green } \\
\text { Island }\end{array}$ & $\begin{array}{l}\text { Does not co-exist with kiore on any Mercury } \\
\text { Islands, but occasionally does so elsewhere }\end{array}$ \\
\hline
\end{tabular}

Arachnida
Cambridgea mercurialis

Orthoptera

(Stenopelmatidae)

Hemideina thoracica

Hemiandrus pallitarsus

Motuweta isolata

Folivore

Predator of invertebrates

Predator of invertebrates

Coleoptera (Tenebrionidae) Algal/fungal grazer

Mimopeus opaculus

Reptilia

(Sphenodontidae)

Sphenodon punctatus

(Gekkonidae)

Dactylocnemis pacificus

Apex terrestrial predator of invertebrates, lizards and small seabirds

Omnivore, nectar, fruit and invertebrates

(Scincidae)

Oligosoma alani

Predator of invertebrates and smaller lizards

Oligosoma oliveri

Predator of invertebrates

Oligosoma suteri

Oligosoma whitakeri
Intertidal predator of invertebrates Predator of invertebrates

\section{Island}

Still to be reintroduced; common in seabird burrows on Middle and Green Islands

52 from Double Island (1997) now widespread and abundant (Green 2005)

Still to be reintroduced; present on Middle and Red Mercury

No data; does not seem to balloon so may have limited dispersal capabilities (M Fitzgerald pers. comm.)

Co-exists with kiore on some Mercury Islands but not others

Co-exists with kiore on some Mercury Islands but not others

100 captive reared originally Does not co-exist with kiore from Middle Island (2007) now locally abundant (unpublished report, Department of Conservation)

100 from Middle Island (2000-2002) now locally abundant (C. Green pers. comm.)

Still to be reintroduced; dense populations on Middle and Green, relict on Stanley and Red

Still to be reintroduced; common in forested areas on Middle

14 reintroduced (1992-93)

from Green; widely

dispersed and locally

abundant

25 reintroduced (1992-93)

from Green; breeding

30 reintroduced 1992 from

Green; locally abundant

28 reintroduced 1988 from Middle; expanding range and locally abundant
Rarely co-exists with kiore; absent from other Mercury Islands invaded by kiore

Coexists with kiore on some other Mercury Islands, but with consistent recruitment failure

Does not co-exist with kiore in Mercury Islands but does in other archipelagos

Does not co-exist with kiore on any islands

Does not co-exist with kiore on any islands

Can co-exist with kiore on islands with appropriate boulder refuges

Does not co-exist with any mammalian predators on islands reintroductions are relatively clear (e.g. Towns \& Ferreira 2001), and include complete replacement of the release propagule with locally born offspring (Wolf et al. 1996). For some invertebrates, high reproductive output and rapid turnover means that such criteria may be achieved in $<10$ years. However, for species such as tuatara, adult life spans of up to 100 years mean that monitoring population replacement will require generations of biologists. In contrast to intervention through reintroductions, passive recovery is undirected and process driven. Nonetheless, passive recovery requires monitoring to assess whether hypotheses about ecosystem development are being met. If success is based on changes in ecosystem function, rather than assemblage composition, progress can be estimated in relatively short time scales (Tables 3 and 4). Measures of the recovery of seabird driven ecosystems can include simple measures of burrow density coupled with additional measures of seabird effects. The study of uninvaded islands and those with seabirds suppressed by invasive mammals (e.g. Fukami et al. 2006; Towns et al. 2009) indicated that soil pH strongly reflects seabird activity. Similarly the measures of $\mathrm{C}: \mathrm{N}$ and $\delta^{15} \mathrm{~N}$ used by Jones (2010) indicate the rate at which seabird effects can be measured. Analyses of food webs on islands with and without procellariiform seabirds indicate the likely responses of ecosystem processes to predator removal if these seabirds recover (Figure 4). Present indications from work on Korapuki Island are that islands within the colonisation range of seabirds could demonstrate many of the functional attributes typical of uninvaded seabird islands within 50 years. More sophisticated investigations of invertebrate community and food web structure should contribute to methods for verifying these functional changes (e.g. Orwin et al. in press). 


\section{Restoration case study: Korapuki Island}

Korapuki was the first island in the Mercury archipelago from which all introduced mammals were removed (kiore in 1986, rabbits in 1987), has been the site where the conceptual and practical impediments to restoration have been tested, and is also the only island in the group with a comprehensive restoration plan (Towns \& Atkinson 2004). The restoration target initially proposed for Korapuki Island by Towns et al. (1990) was for a seabird-reptile-invertebrate-plant system similar to that of Middle and Green Islands. The subsequent restoration plan expanded on this target by emphasizing features of the Middle and Green reference sites, including coexistence of very dense populations of small seabirds (particularly diving petrels) with a high diversity of reptiles and many invertebrate species (Towns \& Atkinson 2004). For extirpated species such as tuatara, five species of lizards and many species of flightless invertebrates, natural recovery is unlikely (Towns 2002b). The restoration plan thus recommends re-introduction of those species likely to have been lost through the action of habitat modification (fire) combined with the previous presence of kiore and rabbits (Table 3). For the purposes of this review, we focus on changes to the biota of Korapuki Island since the removal of mammals in 1986-87 (Tables 2 and 4), restoration activities implemented (Table 3), predicted and unpredicted outcomes, and the many remaining uncertainties in the recovery trajectory of the island (Table 4).

\section{Predicted outcomes}

In order to develop hypotheses for the recovery of Korapuki Island after the removal of kiore and rabbits, Towns \& Atkinson (2004) constructed conceptual interaction webs. The webs were based on structure of the reference ecosystems of Green and Middle Islands and responses elsewhere in the archipelago to mammal eradications. However, it was not possible at that time to define when various predicted interactions would eventuate, nor were criteria identified as measures of success. Central to the 2004 model was an increasing influence from seabirds adding nutrients to the island's soils, and an increasing density of seabird burrows, which are used as habitat by tuatara and some species of lizards. The speed at which burrow-nesting seabird populations recover was assumed to rest on three aspects of the biology of Procellariiformes: extreme philopatry; low annual reproductive output; and slow development to reproductive maturity (e.g. Warham 1996). In combination with slow population growth by introduced species of reptiles (e.g. Towns 1994), reactivation of the proposed interaction web was assumed to involve timescales of decades or perhaps centuries.

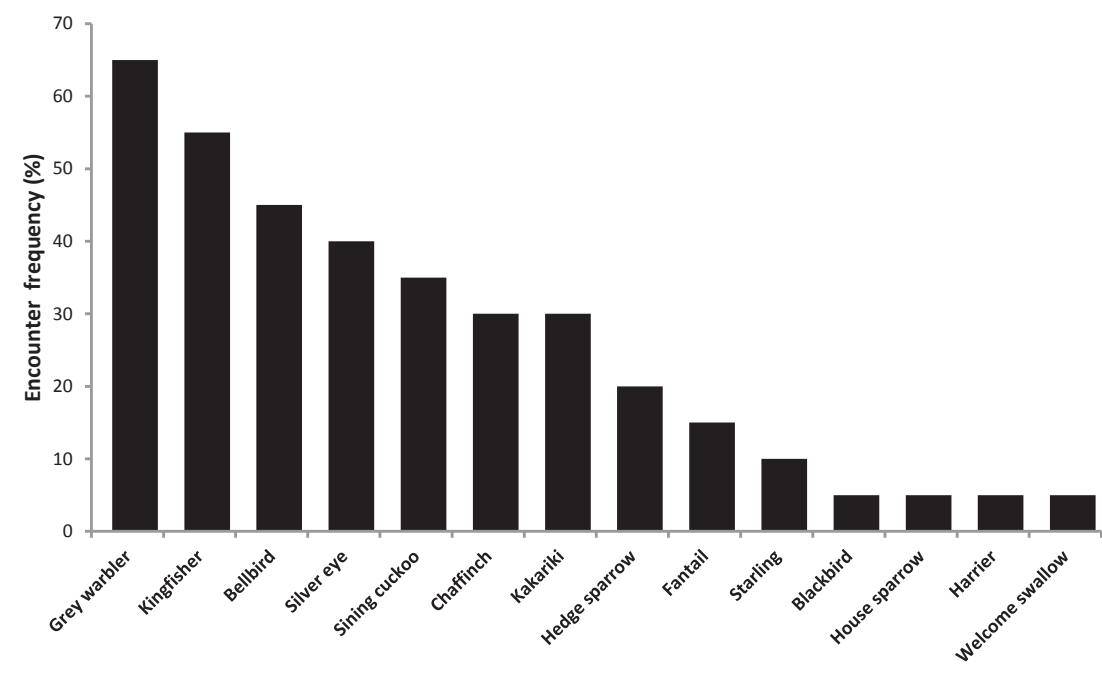

Figure 3. Frequency of forest bird encounters (presence/absence of calls and sightings) at 20 five-minute observation points at $50 \mathrm{~m}$ intervals along axial ridges on Korapuki Island in December 2007.

$\square$ Seabird $\square$ Rat

Figure 4. Relative abundance of litter invertebrates from different trophic levels on nine northeastern New Zealand islands invaded by rats and with few seabirds compared with nine islands in the same geographic area never invaded by introduced mammals (for methods and study sites see Towns et al. 2009); Mann-Whitney U Tests were used to compare means with $\mathrm{p}$ values identified as $* \mathrm{p}<0.05$, $* * \mathrm{p}<0.005, * * * \mathrm{p}<0.0005$

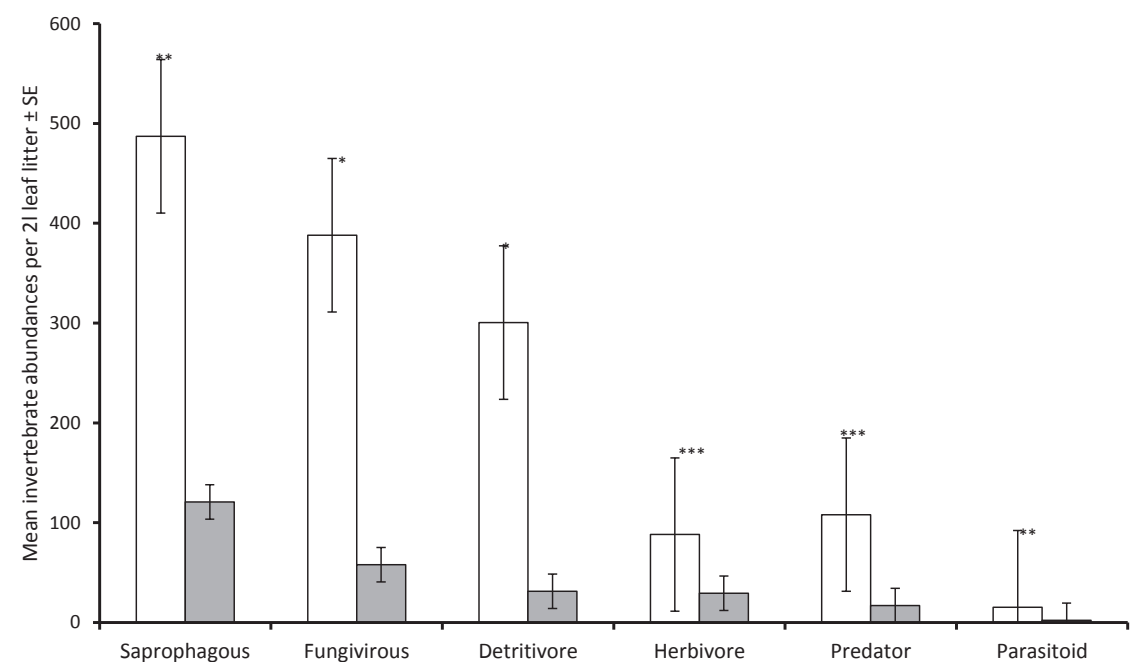


Table 3. Changes to biota of Korapuki Island following the removal of kiore and rabbits.

\begin{tabular}{lll}
\hline Species or taxonomic group & Before mammal removal & At least 20 years after mammal removal \\
\hline Plants & $\begin{array}{l}\text { Flora of 96 species (Hicks et al. 1975), } \\
\text { with 74\% native }\end{array}$ & $\begin{array}{l}\text { Flora of 115 species with 79\% native immediately after } \\
\text { kiore and rabbit removal (1988); 128 species with 81\% } \\
\text { native by 2002 (Towns \& Atkinson 2004) }\end{array}$ \\
$\begin{array}{l}\text { Selected woody plants } \\
\text { sensitive to kiore }\end{array}$ & $\begin{array}{l}\text { Restricted to }<10 \text { known individuals } \\
\text { or previously listed as uncommon } \\
\text { (a few at one or two locations): }\end{array}$ & $\begin{array}{l}\text { All species except C. laevigatus (spreading but }<10 \\
\text { individuals) now present throughout island; } P . \text { costata }\end{array}$ \\
& $\begin{array}{l}\text { Coprosma repens; Corynocarpus } \\
\text { laevigatus; Melycitus novaezealandiae; } ; 80 \text { young plants in some areas (Towns et al. }\end{array}$ & 1997; Towns \& Atkinson 2004)
\end{tabular}

$\begin{array}{ll}\text { Invertebrates } & \text { Few large invertebrates (beetles and } \\ \text { millipedes) }>10 \mathrm{~mm} \text { seen; no other data } \\ \text { (Hicks et al. 1975) }\end{array}$

Reptiles

Seabirds

Native land birds
Five species of lizards recorded but only four of these seen by Hicks et al. (1975): Oligosoma aenea, not seen; Woodworthia maculata and Hoplodactylus duvaucelii $<10$ seen; O. smithi and O. moco, regarded as common

Eight species listed, seven of which recorded by Hicks et al. (1975): Eudyptula minor, throughout; Puffinus carneipes, few seen; $P$. griseus, four seen; $P$. gavia, second-most abundant, $<19 /$ ha; $P$. assimilis, scattered burrows $<6.8 /$ ha; Pterodroma macroptera, most common species $<36 /$ ha, $600-700$ pairs total; Pelecanoides urinatrix, scattered, one site ca $30 /$ ha

Eleven species of native birds and four exotic species recorded by Hicks et al. (1975), with native species classed as abundant: Cyanoramphus novaeseelandiae, Rhipudura fuliginosa, Gerygone igata and Zosterops lateralis. Classed as frequent: Circus approximans. Classed as uncommon: Ninox novaeseelandiae, Halcyon sancta, Anthornis melanura and Prosthemadera novaeseelandiae
Reappearance of three species of native cockroaches, small wēta Neonetus? sp. large centipede Cormocephalus rubriceps (Towns et al. 1997) and honeydew scale Coelostomidium zealandica (Towns $2002 \mathrm{~b}$ ); identification of 24 species of terrestrial molluscs (includes one exotic species of slug) and 70 species of spiders (Towns \& Atkinson 2004)

O. aenea trapped in all forest habitats by 1999 (D Towns unpublished data); demographic shifts and habitat changes recorded for O. smithi (Towns 1991) and H. duvacellii (Towns 1996); increased capture frequencies of all five species (Monks et al. 2014); sighting frequencies of $W$. maculata on coast exceeded Middle Island within 15 years of mammal eradication (Towns 2002b)

Phalacrocorax varius observed by Hicks et al. (1975) in coastal waters, but now breeding in pōhutukawa on SW coast

Hirudo tahitica not recorded by Hicks et al. (1975), but now seen around the entire coastline (Towns \& Atkinson 2004); three species classed as uncommon are now widespread and abundant throughout the island but $P$. novaeseelandiae only reported by A Evans (Unpublished data)

\section{Unpredicted outcomes}

Avian predators

Many responses to invasive mammal removals from Korapuki were unpredicted, including the resurgence and recolonisation of two avian predators: the kingfisher (Todiramphus sanctus) and the native owl (morepork; Ninox novaeseelandiae). Both species were regarded as uncommon by Hicks et al. (1975) and only a single pair of kingfishers was recorded by a survey in 1985 (D. Towns unpublished data). However, in 2007 kingfishers were encountered in over half of the survey sites used (Figure 3).

Moreporks were only occasionally sighted during biennial visits between 1985 and 2009, most likely as visitors from neighbouring islands, as there were no observed territorial calls. By 2009 territorial calls were heard, and in March 2011 moreporks calls were heard across the entire island (D. Towns unpublished data). Moreporks and kingfishers feed on lizards, large invertebrates and small birds (Robertson 1985). Recovery and recolonisation by these two avian predators could thus be an indirect measure of the increased abundance of their prey, one item of which for moreporks is tree wēta reintroduced to Korapuki in 1997 (Table 2).

\section{Insect parasites}

Honeydew scale insects are parasites of many forest plant species in New Zealand (Morales 1991). Their role in providing a high energy carbohydrate resource for birds and lizards on islands was unknown until the appearance of coastal forest plants infested by scale insects Coelostomidia zealandica on Korapuki (Towns 2002a). As these parasites have gradually spread, the importance of honeydew and other sources of sugar to geckos on these islands has also become apparent. Common geckos (Woodworthia maculata) are now common around flax (Phormium tenax), where they feed from inflorescences and sap. 
Table 4. Chronological measures of progress and success for restoration of communities within a seabird-driven ecosystem of Korapuki Island; with projected measures $>25$ years.

\begin{tabular}{lll}
\hline $\begin{array}{l}\text { Years since eradication of } \\
\text { invasive mammals }\end{array}$ & Measure & Comment \\
\hline 10 & $\begin{array}{l}\text { Dispersal to/within island of } \\
\text { key canopy plant species }\end{array}$ & $\begin{array}{l}\text { Dominant species of communities on Middle Island as reference site } \\
\text { spreading via bird dispersal (Towns \& Atkinson 2004) but likely } \\
\text { additional species (e.g. kohekohe) yet to establish (Atkinson 2004) }\end{array}$ \\
20 & $\begin{array}{l}\text { Establishment of selected } \\
\text { missing invertebrates and }\end{array}$ & $\begin{array}{l}\text { Five years for establishment of some invertebrates (e.g. Green 2005) } \\
\text { and }>8 \text { years for some lizards (Towns \& Ferreira 2001) }\end{array}$
\end{tabular}

$20-25$ reptiles

50 Recolonisation of top resident avian predator Marine signature via seabirds within range of uninvaded islands

$50-100$

Complete infestation of potential hosts for honey dew scale; time required to define success for reintroductions of tuatara Carrying capacity reached for reintroduced reptiles with low annual reproductive output Replacement of continuous pōhutukawa canopy by diverse coastal species

Moreporks resident (based on territorial calls), but likely contingent on establishment of large invertebrates including tree wēta

$\mathrm{C}: \mathrm{N}$ and $\delta^{15} \mathrm{~N}$ concentrations in soils and plants equivalent to islands with unsuppressed seabird populations (extrapolated from Jones 2010); high density seabird colonies present but localised (Buxton et al. 2016)

About $20 \%$ of island with honeydew infested karo or ngaio plants (Evans et al. 2015); successful reintroductions with each population composed of F1 or greater (D. Towns unpublished data)

Modelled time to carrying capacity for Whitaker's skink (Miller 2009) and likely minimum time for tuatara; density of both species linked to seabird burrow density

Likely gradual change from pōhutukawa to karaka (Corynocarpus laevigatus) and kohekohe, but may depend on effects of seabirds

Duvaucel's geckos (Hoplodactylus duvaucelii) and common geckos are also found on the host trees for honeydew scale, although Duvaucel's geckos are the more abundant at such sites (Evans et al. 2015). Furthermore, bellbirds (Anthornis melanura) are often now seen feeding on the honeydew and vocally defending productive scale-infested karo (Pittosporum crassifolium) trees (D. Towns unpublished data).

\section{Seabird recovery and recolonisation}

The speed at which seabirds have recolonised and influenced restored island ecosystems in New Zealand has confounded assumptions based on philopatry and low immigration rates (Croxall et al. 2012; Kappes \& Jones 2014). Through studies of $\mathrm{C}: \mathrm{N}$ ratios and the concentration of $\delta^{15} \mathrm{~N}$ in soils, foliage and spiders, Jones (2010) concluded that ecosystem recovery on northeastern New Zealand islands may be achieved in decades. These conclusions were supported by Buxton et al. (2014), who found that on islands $<25 \mathrm{~km}$ from other dense seabird colonies, intra- and interspecific social attraction can stimulate immigration to previously depleted colonies or establish new ones. These findings were particularly relevant to Korapuki Island, which at the longest time since eradication of mammals (then 22 years) had the highest soil and plant $\delta^{15} \mathrm{~N}$ and lowest C:N of the islands sampled (Jones 2010). In contrast to the scattered low density colonies recorded 10 years before mammal eradication (Hicks et al. 1975), seabird colonies now extend over $70 \%$ of surveyed areas on the island (Buxton et al. 2016).

\section{Mysterious declines and disappearances}

Surprisingly, we found changes in the abundance and distribution of resident species initially thought to be resistant to the effects of kiore and rabbits. For example, the diurnal shore skink (Oligosoma smithi) was regarded as abundant in the presence of kiore and rabbits (Hicks et al. 1975).
However, surveys revealed changes in distribution, increases in mean body size, and increased capture frequency soon after mammals were eradicated (Towns 1991, 1996; Monks et al. 2014). Conversely, recent samples indicate declines in the capture rates of shore skinks, while captures of other species of resident and translocated lizards continue to increase at the same sites (D. Towns unpublished data). Whether the current declines of shore skink captures is related to competition or predation from other species of lizards or the increased density of kingfishers as predators remains unclear.

In their early surveys of Korapuki Island, Hicks et al. (1975) observed few large day-flying insects and noted that the only species observed were cicadas and wasps. We assume that the latter were introduced Vespula wasps, since these were still present during our visits 10 years later (C. Green pers. comm.). In New Zealand, these wasps compete with birds for honeydew, can kill nestling birds, and prey heavily on spiders and caterpillars, resulting in modified invertebrate community structure (Beggs 2011). Within five years of the mammal eradication these wasps disappeared and have not been seen since (Bellingham et al. 2010a). Similar disappearances have now been observed on other islands after eradication of rats, including very large islands where Vespula wasps were once extremely abundant (T. Lovegrove pers. comm.).

Failed colonisations and unknown consequences Numerous uncertainties remain about the composition and dynamics of communities on Korapuki Island. For example, seed dispersal will inevitably shape forest composition, which for some species requires kererū visiting from neighbouring islands (Towns \& Atkinson 2004). The presence of tawāpou and taraire provides evidence of kererū visitation to Korapuki. However, not all species imported by kererū survive. In 1986, three taraire plants appeared to be thriving on the southwestern part of Korapuki; however, all plants succumbed after a drought 
in the early 1990s and none have been seen since. Other species that are dispersed to the island may germinate only to be destroyed by drought, trampling or clipping by seabirds.

The relatively rapid increase in seabird activity brings additional uncertainties for longer term successional processes. In some areas of Korapuki, seabird burrow density is high under a canopy of 100-year old pōhutukawa (Metrosideros excelsa) that developed as a result of burning and the activities of rabbits (Atkinson 2004). Long term, this canopy would likely be replaced by a variety of coastal species, but the intense seabird activity could suppress seedling growth and arrest succession. Because Korapuki has a wide range of habitats and soil depths (Towns \& Atkinson 2004) such effects are likely to be localised.

Finally, the recovery trajectory of Korapuki will likely be affected by external influences (Towns 2002b), such as climate change, ocean pollution, and other conservation actions. The latter could include success with mammal eradications on other islands in the archipelago. If the eradication of invasive mammals from Great Mercury in 2014 proves to be successful (Supplementary Data), all Mercury Islands will be free of introduced mammals. It is likely that kererū numbers will correspondingly increase, which in turn will increase the frequency of their movements between islands. The resulting seed dispersal could include species currently absent from islands such as Korapuki, with outcomes that at present are unknown. Another conservation action that may elicit indirect consequences on the recovery trajectory of Korapuki is the protection of New Zealand fur seals (Arctocephalus forsteri) following heavy exploitation in the $19^{\text {th }}$ century (Harcourt 2005). The species is now reclaiming its former range, which includes sightings in 2012 of male fur seals ashore on Korapuki Island (A. Evans unpublished data). Rookeries may be established on Korapuki Island at some stage, which could significantly modify coastal vegetation, as well as contribute nutrient subsidies to the ecosystem. How fur seals might influence the function of these warm temperate ecosystems remains unclear.

\section{Discussion}

Invasive mammals have been eradicated from seven of the islands in the MIED. These eradications included some of the earliest campaigns against rodents, beginning with kiore (and rabbits) on Korapuki Island in 1986, and eventually leading to cats and rats on the eighth and largest of the islands (Great Mercury; 1872 ha), which began in 2014. With almost 30 years free of introduced mammals, Korapuki Island has been invaluable for testing concepts associated with island restoration as well as methods for species reintroductions. For example, a restoration target to "extend the area of unique seabird-reptile-invertebrate-plant communities" typical of the Mercury Islands was proposed soon after eradications were completed on Korapuki (Towns et al. 1990), but was not developed into a completed restoration plan until much later (Towns \& Atkinson 2004). Empirical support for the pivotal role of seabirds, as implied in the restoration target, is even more recent (e.g. Fukami et al. 2006; Mulder et al. 2011). The evolution of ideas and collection of supporting data for restoration of these islands was built around four components: biogeography; ecosystem function; the effects of invasive species; and outcome measures (Figure 5). For example, through testing biogeographic theory, our work suggests that assemblage structure may be most easily predicted on islands previously part of the mainland, but especially those once interconnected.

We have also found that ecosystem function can be determined from two sources: the way resident species respond when invasive species are removed and the use of comparative data from reference sites never occupied by invasive mammals. Reference models are likely to be most instructive when on islands of similar size to the site being restored. As island size increases, reference sites uninvaded by introduced mammals become increasingly rare and for islands $>1000$ ha do not exist (Parkes \& Murphy 2003). However, on some of the larger islands, past assemblage composition can be revealed from the bone fragments, pollen and ancient DNA used for archaeological and palaeoecological studies (Bellingham et al. 2010a; Wilmshurst et al. 2014).

Regardless of the availability of reference sites, the amount of restoration effort required is determined by recolonisation ability; this may vary for seabirds according to the distance from source populations but is consistently poor for reptiles and some terrestrial invertebrates. Finally, restoration endpoints can be defined by combining biogeographic origin, post eradication responses and ecosystem function. For example, a restored seabird-driven ecosystem on Korapuki Island with high ecological integrity typical of the archipelago acknowledges historic vicariance, high rates of natural recolonisation by plants and seabirds, but the extirpation of key reptiles and large flightless invertebrates. However, despite the three decades of reintroductions and recovery on the island, measures of progress towards the restoration endpoints are still in development.

In sum, ecological restoration in the Mercury Islands indicates that the "Humpty Dumpty" problem raised by Duffy (1994) and others who have examined the ambiguity of island restoration (Simberloff 1990) can be addressed within a defensible framework. However, our studies have also revealed many unexpected responses to invasive mammal removal. There are also unpredictable consequences of the previous presence of mammals, responses of species such as kererū to conservation actions elsewhere and the effects of recolonisation of the islands by fur seals. Conversely, there is developing clarity about how these seabird driven systems vary under different climatic and biogeographic regimes and the extent to which they can be modified by introduced animals. Insights have come from comprehensive studies of the general relationships between seabird activity, nutrient subsidy, and vegetation composition beginning in the 1950s (e.g. Gillham 1956a, b), complemented locally by analyses of seabird-soil-plant relationships on Middle Island in the Mercury Group (Atkinson 1964), and extended by studies across islands in northern New Zealand (Fukami et al. 2006) and globally (Mulder et al. 2011). The studies by Jones (2010) and ourselves in the Mercury Islands indicate that removal of predatory mammals can lead to reactivation of the seabird influence on island ecosystems, as long as the birds can recolonise. Furthermore, Buxton et al. (2014) show that there is frequently natural recolonisation of islands $<25 \mathrm{~km}$ from other large seabird colonies. Collectively, these recent studies indicate that seabird-driven ecosystems in some locations can recover rapidly, but they have also identified markers that can be used to measure the extent of that recovery.

Given that the seabird-driven ecosystem on Korapuki appears to be recovering naturally (Jones 2010; Buxton et al. 2016), is restoration based on pre-determined assemblage composition justified? For example, the ecosystem on Korapuki 


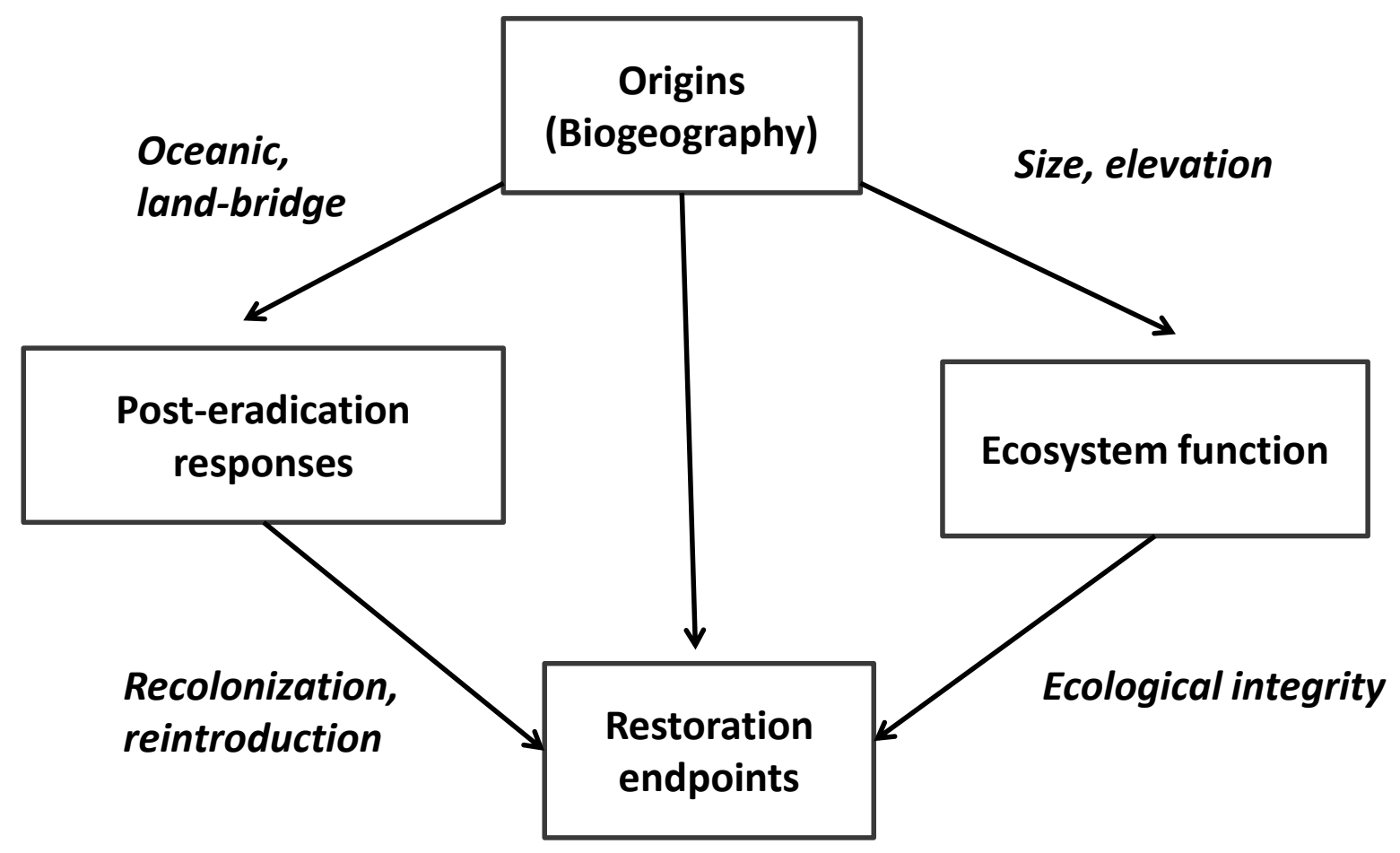

Figure 5. Summary of the relationship between four key components of island restoration.

will not cease to function in the absence of tuatara, which will simply be replaced by Duvaucel's geckos as top reptile predator (Towns 2002b). Furthermore, should we be concerned if ecosystems on islands beyond the natural colonisation range of seabirds enter alternative stable states unlike those with invasive mammals but no longer driven by the engineering effects of seabirds (e.g. Mulder et al. 2009)? Such questions lead us into the realm of value judgements. By phrasing his problem in the context of a children's nursery rhyme, Duffy (1994) implies a social component to restoration, as there is with all conservation biology (e.g. Lawton 1997). One social dimension applied to our study at the outset: a legal framework (i.e. a statutory expression of values) within which to conduct the eradications and attempt ecosystem restoration. Work in the Mercury Islands began on sites administered as Nature Reserves, which mandates the removal of all exotic species where possible (Reserves Act 1977). We therefore assumed that the implicit goal of the reserves is protecting or promoting the highest possible ecological integrity (sensu Lee et al. 2005), which on Korapuki includes reintroduction of invertebrates and reptiles (Towns \& Atkinson 2004). Nonetheless, even with a legal mandate, when multiple stakeholders are involved there can still be heated debate when invasive species eradications are proposed, as was the case before the removal of kiore from Hauturu (Little Barrier) Island Nature Reserve (Towns et al. 2006). Accordingly, our summary of the essential elements to be considered when undertaking restoration of islands (Figure 5 ) is a simplified view that excludes the complex regional social issues that may be involved.

Having acknowledged uncertainties about the successional consequences of natural recovery supplemented by reintroductions, our approach on Korapuki has been to allow the ecosystem to develop at its own speed. By facilitating the return of only those components unable to recolonise unaided, we assume that the system will eventually follow a trajectory typical of other regional islands of equivalent size (Simberloff 1990; Towns 2002b). What still remains unclear from the Korapuki study is whether the strong ecosystem engineering effects of seabirds apply on larger islands, or whether such locations develop into more heterogeneous environments than are found on our small reference islands, such as Middle. Consequently, a great deal is still to be learned from the processes of recovery on other Mercury Islands such as Red Mercury, which is over 20 times larger than their available reference sites within the archipelago.

\section{Acknowledgements}

We wish to thank James Russell for inviting our contribution to the workshop on rodent eradications. The ideas presented here have benefited from extensive discussions on Korapuki, especially with IanAtkinson, Chris Green and Mike Fitzgerald. Infrastructural support for work on the island has frequently been provided by Rob Chappell from the Department of Conservation, for which we express our sincere thanks. We also thank Chris Green, Cheryl Krull, James Russell and two anonymous reviewers for their useful comments on drafts of the manuscript.

\section{References}

Atkinson IAE 1964. The flora, vegetation, and soils of Middle and Green Island, Mercury Islands group. New Zealand Journal of Botany 2: 385-402.

Atkinson IAE 1985. The spread of commensal species of Rattus to oceanic islands and their effects on island avifauna. In: Moors PJ ed Conservation of island birds. Cambridge, UK, ICBP. Pp. 35-81.

Atkinson IAE 1986. Rodents on New Zealand's northern 
offshore islands: distribution, effects and precautions against further spread. In: Wright AE, Beever RE eds The offshore islands of northern New Zealand. Department of Lands and Survey Information Series No. 16. Pp. 13-40.

Atkinson IAE 1988. Presidential address: opportunities for ecological restoration. New Zealand Journal of Ecology 11: $1-12$.

Atkinson IAE 2004. Successional processes induced by fires on the northern offshore islands of New Zealand. New Zealand Journal of Ecology 28: 181-193.

Balaguer L, Escudero A, Martín-Dubuque JF, Mola I, Aronson J 2014. The historical reference in restoration ecology: re-defining a cornerstone concept. Biological Conservation 176: $12-20$

Beggs J 2011. Wasps. In: Simberloff D, Rejmánek M eds Encyclopedia of biological invasions. Berkeley, University of California Press. Pp. 685-689.

Bellingham P, Towns DR, Cameron EK, Davis JJ, Wardle DA, Wilmshurst JM, Mulder C 2010a. New Zealand island restoration: seabirds, predators, and the importance of history. New Zealand Journal of Ecology 34: 115-136.

Bellingham PJ, Wiser SK, Wright AE, Cameron EK, Forester LJ 2010b. Disperser communities and legacies of goat grazing determine forest succession on the remote Three Kings Islands, New Zealand. Biological Conservation 143: 926-938.

Borrelle SB, Buxton RT, Jones HP, Towns DR 2015. A GISbased decision making approach for prioritizing seabird management following predator eradication. Restoration Ecology 23:580-587.

Burger AE 2005. Dispersal and germination of seeds of Pisonia grandis, an Indo-Pacific tropical tree associated with insular seabird colonies. Journal of Tropical Ecology 21: $263-271$.

Buxton RT 2014. Ecological drivers of seabird recovery after the eradication of introduced predators. PhD Thesis. Dunedin, University of Otago. 209 p.

Buxton RT, Jones CJ, Moller H, Towns DR 2014. Drivers of seabird population recovery on New Zealand islands after predator eradication. Conservation Biology 28: 333-344.

Buxton RT, Taylor G, Jones C, Lyver PO'B, Moller H, Cree A, Towns DR 2016. Spatio-temporal changes in density and distribution of burrow-nesting seabird colonies after rat eradication. New Zealand Journal of Ecology 40: 88-99.

Campbell DJ, Atkinson IAE 1999. Effects of kiore (Rattus exulans Peale) on recruitment of indigenous coastal trees on northern offshore islands of New Zealand. Journal of the Royal Society of New Zealand 29: 265-290.

Campbell DJ, Atkinson IAE 2002. Depression of tree recruitment by the Pacific rat (Rattus exulans Peale) on New Zealand's northern offshore islands. Biological Conservation 107: 19-35.

Carlquist S 1965. Island Life. Garden City, New York, Natural History Press. 451 p.

Croxall JP, Butchart SHM, Lascelles B, Sattersfield AJ, Sullivan B, Symes A, Taylor P 2012. Seabird conservation status, threats and priority actions: a global assessment. Bird Conservation International 22: 1-34.

Daugherty CH, Towns DR, Atkinson IAE, Gibbs GW 1990. The significance of the biological resources of New Zealand islands for ecological restoration. In: Towns DR, Daugherty $\mathrm{CH}$, Atkinson IAE eds Ecological restoration of New Zealand islands. Wellington, Department of Conservation. Pp. 9-21.
Duffy DC 1994. Afterwards: an agenda for managing seabirds and islands. In: Nettleship DN, Burger J, Gochfeld M eds Seabirds on islands: threats, case studies and action plans, Vol 1. Birdlife Conservation Series. 318 p.

Evans AE, Towns DR, Beggs JR 2015. The relative importance of sugar resources to endemic gecko populations in an isolated island ecosystem. New Zealand Journal of Ecology 39: 262-272.

Fukami T, Wardle DA, Bellingham PJ, Mulder CPH, Towns DR, Yeates GW, Bonner KI, Durrett MS, Grant-Hoffman MN, Williamson WM 2006. Above- and below-ground impacts of introduced predators in seabird-dominated island ecosystems. Ecology Letters 9: 1299-1307.

Gillham ME 1956a. Ecology of the Pembrokeshire Islands. IV. Effects of treading and burrowing by birds and mammals. Journal of Ecology 44: 51-82.

Gillham ME 1956b. Ecology of the Pembrokeshire Islands. V. Manuring by the colonial seabirds and mammals, with a note on seed distribution by gulls. Journal of Ecology 44: 429-454.

Green C 2005. Using artificial refuges to translocate and establish Auckland tree weta Hemideina thoracica on Korapuki Island, New Zealand. Conservation Evidence 2: 94-95.

Harcourt R 2005. New Zealand fur seal. In: King CM ed The handbook of New Zealand mammals. Melbourne, Oxford University Press. Pp. 225-235.

Hayward BW 1986. Origin of the offshore islands of northern New Zealand and their landform development. In: Wright AE, Beever RE eds The offshore islands of northern New Zealand. Department of Lands and Survey Information Series No. 16. Pp. 129-138.

Hicks GRF, McColl HP, Meads MJ, Hardy GS, Roser RJ 1975. An ecological reconnaissance of Korapuki Island, Mercury Islands. Notornis 22: 195-220.

Howald G, Donlan CJ, Galván JP, Russell JC, Parkes J, Samaniego A, Wang Y, Veitch D, Genovesi P, Pascal M, Saunders A, Tershy B 2007. Invasive rodent eradication on islands. Conservation Biology 21: 1258-1268.

Jones HP 2010. Seabird islands take mere decades to recover following rat eradication. Ecological Applications 20: 2075-2080

Kappes P, Jones H 2014. Integrating seabird restoration and mammal eradication programs on islands to maximize conservation gains. Biodiversity and Conservation 23: 503-509.

Keitt B, Campbell K, Saunders A, Clout M, Wang YW, Tershy B 2011. The global islands invasive vertebrate eradication database: a tool to improve and facilitate restoration of island ecosystems. In: Veitch CR, Clout MN, Towns DR eds Island invasives: eradication and management. Gland, Switzerland and Auckland, New Zealand, IUCN. Pp. 74-77.

Lawton JH 1997. The science and non-science of conservation biology. New Zealand Journal of Ecology 21: 117-120.

Lee W, McGlone M, Wright E 2005. Biodiversity inventory and monitoring: a review of national and international systems and a proposed framework for future biodiversity monitoring by the Department of Conservation. Landcare Research Contract Report LC0405/122. 213 p.

McArthur RH, Wilson EO 1967. The theory of island biogeography. Princeton, Princeton University Press. 203 p.

McEwen WM 1987. Ecological regions and districts of New 
Zealand. Wellington, Department of Conservation. $63 \mathrm{p}$. Merton D 1987. Eradication of rabbits from Round Island, Mauritius: a conservation success story. Dodo 24: 19-43.

Miller KA 2009. Founding events and the maintenance of genetic diversity in reintroduced populations. $\mathrm{PhD}$ Thesis. Wellington, Victoria University of Wellington. 125 p.

Monks JM, Monks A, Towns DR 2014. Correlated recovery of five lizard populations following eradication of invasive mammals. Biological Invasions 16: 167-175.

Morales CF 1991. Margarodidae (Insecta: Hemiptera). Fauna of New Zealand 21. 124 p.

Mulder CPH, Keall SN 2001. Burrowing seabirds and reptiles: impacts on seeds, seedlings and soils in an island forest in New Zealand. Oecologia 127: 350-360.

Mulder CPH, Grant-Hoffman MN, Towns DR, Bellingham PJ, Wardle DA, Durrett MS, Fukami T, Bonner KI 2009. Direct and indirect effects of rats: does rat eradication restore ecosystem functioning of New Zealand islands? Biological Invasions 11: 1671-1688.

Mulder CPH, Anderson WB, Towns DR, Bellingham PJ 2011. Seabird islands: ecology, invasion and restoration. New York, Oxford University Press. 512 p.

Norton DA 2009. Species invasions and limits to restoration: learning from the New Zealand experience. Science 325: 569-571.

O’Dowd DJ, Green PT, Lake PS 2003. Invasional 'meltdown' on an oceanic island. Ecology Letters 6: 812-817.

Orwin KH, Wardle DA, Towns DR, St. John MG, Bellingham PJ, Jones C, Fitzgerald BM, Parrish RG, Lyver PO'B in press. Burrowing seabird effects on invertebrate communities in soil and litter are dominated by ecosystem engineering rather than nutrient addition. Oecologia.

Parkes J, Murphy E2003. Management of introduced mammals in New Zealand. New Zealand Journal of Zoology 30: 335-359.

Pickard CR, Towns DR 1988. Atlas of the amphibians and reptiles of New Zealand. Conservation Sciences Publication No 1. Wellington, Department of Conservation. $59 \mathrm{p}$.

Robertson CJR 1985. Readers Digest complete book of New Zealand birds. Sydney, Readers Digest. 319 p.

Russell JC 2011. Indirect effects of introduced predators on seabird islands. In: Mulder CPH, Anderson WB, Towns DR, Bellingham PJ eds Seabird islands: ecology, invasion, and restoration. New York, Oxford University Press. Pp. 261-279.

Russell JC, Holmes ND 2015. Tropical island conservation: rat eradication for species recovery. Biological Conservation 185: $1-7$.

Simberloff D 1990. Reconstructing the ambiguous: can island ecosystems be restored? In: Towns DR, Daugherty $\mathrm{CH}$, Atkinson IAE eds. Ecological restoration of New Zealand islands. Wellington, Department of Conservation. Pp. 37-51.

Tershy BR, Shen K-W, Newton KM, Holmes ND, Croll DA 2015. The importance of islands for the protection of biological and linguistic diversity. BioScience 65: 592-597.

Towns DR 1988. Rodent eradication from islands - the conservation potential. Forest and Bird 19: 32-33.

Towns DR 1991. Response of lizard assemblages in the Mercury Islands, New Zealand, to removal of an introduced rodent: the kiore (Rattus exulans). Journal of the Royal Society of New Zealand 21: 119-36.
Towns DR 1994. The role of ecological restoration in the conservation of Whitaker's skink (Cyclodina whitakeri), a rare New Zealand lizard (Lacertilia: Scincidae). New Zealand Journal of Zoology 21: 457-471.

Towns DR 1996. Changes in habitat use by lizards on a New Zealand island following removal of the introduced Pacific rat Rattus exulans. Pacific Conservation Biology 2: 286-92.

Towns DR 2002a. Interactions between geckos, honeydew scale insects and host plants revealed on islands in northern New Zealand, following eradication of introduced rats and rabbits. In: Veitch CR, Clout MN eds Turning the tide: the eradication of invasive species. Gland, Switzerland and Cambridge UK, IUCN. Pp. 329-335.

Towns DR 2002b. Korapuki Island as a case study for restoration of insular ecosystems in New Zealand. Journal of Biogeography 29: 593-608.

Towns DR 2009. Eradications as reverse invasions: lessons from Pacific rat (Rattus exulans) removals from New Zealand islands. Biological Invasions 11: 1719-1733.

Towns DR 2011. Eradication of vertebrate pests from islands around New Zealand: what have we delivered and what have we learned? In: Veitch CR, Clout M, Towns DR eds Island invasives: eradication and management. Gland, Switzerland and Auckland, New Zealand, IUCN. Pp. 364-371.

Towns DR, Atkinson IAE 1991. New Zealand's restoration ecology. New Scientist 1765: 36-39.

Towns DR, Atkinson IAE 2004. Restoration plan for Korapuki Island (Mercury Islands), New Zealand. Wellington, Department of Conservation. $52 \mathrm{p}$.

Towns DR, Ballantine WJ 1993. Conservation and restoration of New Zealand island ecosystems. Trends in Ecology and Evolution 8: 452-457.

Towns DR, Broome KG 2003. From small Maria to massive Campbell: forty years of rat eradications from New Zealand islands. New Zealand Journal of Zoology 30: 377-398.

Towns DR, Ferreira SM 2001. Conservation of New Zealand lizards (Lacertilia: Scincidae) by translocation of small populations. Biological Conservation 98: 211-222.

Towns DR, Atkinson IAE, Daugherty CH 1990. The potential for ecological restoration in the Mercury Islands. In: Towns DR, Daugherty CH, Atkinson IAE eds Ecological restoration of New Zealand islands. Conservation Sciences Publication No. 2. Wellington, New Zealand, Department of Conservation. Pp. 91-108.

Towns DR, Atkinson IAE, Daugherty CH 2006. Have the harmful effects of introduced rats on islands been exaggerated? Biological Invasions 8: 863-891.

Towns DR, Byrd GV, Jones HP, Rauzon MJ, Russell JC, Wilcox C 2011. Impacts of introduced predators on seabirds. In: Mulder CPH, Anderson WB, Towns DR, Bellingham PJ eds Seabird islands: ecology, invasion, and restoration. New York, Oxford University Press. Pp. 56-90.

Towns DR, Parrish GR, Tyrrell CL, Ussher GT, Cree A, Newman DG, Whitaker AH, Westbrooke I 2007. Responses of tuatara (Sphenodon punctatus) to removal of Pacific rats from islands. Conservation Biology 21: 1021-1031.

Towns DR, Simberloff D, Atkinson IAE 1997. Restoration of New Zealand islands: redressing the effects of introduced species. Pacific Conservation Biology 3: 99-124.

Towns DR, Wardle DA, Mulder CPH, Yeates GW, Fitzgerald BM, Parrish GR, Bellingham PJ, Bonner KI 2009. Predation of seabirds by invasive rats: multiple indirect 
consequences for invertebrate communities. Oikos 118: 420-430.

Towns DR, West CK, Broome KG 2013. Purposes, outcomes and challenges of eradicating invasive mammals from New Zealand islands: an historical perspective. Wildlife Research 40: 94-107.

Veltman CJ 1996. Investigating causes of population decline in New Zealand plants and animals: introduction to a symposium. New Zeal Journal of Ecology 20: 1-5.

Wardle DA, Bellingham PJ, Boot KI, Mulder CPH 2009. Indirect effects of invasive predators on plant litter quality, decomposition and nutrient resorption on seabirddominated islands. Ecology 90: 452-464.

Warham J 1996. The behaviour, population biology and physiology of petrels. London, Academic Press. 616 p.

Watt JC 1986. Beetles (Coleoptera) of the offshore islands of northern New Zealand. In: Wright AE, Beever RE eds The offshore islands of northern New Zealand. Department of Lands and Survey Information Series No. 16. Pp. 221-228.
Whitaker AH 1978. The effects of rodents on reptiles and amphibians. In: Dingwall PR, Atkinson IAE, Hay C eds The ecology and control of rodents in New Zealand nature reserves. Information Series 4. Wellington, Department of Lands and Survey. Pp. 75-86.

Wilmshurst JM, Moon NT, Wood JR, Bellingham PJ, Findlater AM, Robinson JJ, Stone C 2014. Use of pollen and ancient DNA as conservation baselines for offshore islands in New Zealand. Conservation Biology 28: 202-212.

White PS, Walker JL 1997. Approximating nature's variation: selecting and using reference information in restoration ecology. Restoration Ecology 5: 338-349.

Wiley EO 1988. Vicariance biogeography. Annual Review of Ecology and Systematics 1988: 513-542.

Wolf GM, Griffith B, Reed C, Temple SA 1996. Avian and mammalian translocations: an update and reanalysis of 1987 survey data. Conservation Biology 10: 1142-1154. 
Supplementary Data. Rodents and associated species eradicated from Islands in Mercury Islands Ecological District (McEwen 1987) in chronological sequence updated from Towns \& Broome (2003).

\begin{tabular}{|c|c|c|c|c|c|c|c|}
\hline Location & Area (ha) & Status & Date & Rodent & $\begin{array}{l}\text { Other } \\
\text { eradications }\end{array}$ & Method used against rodents & References \\
\hline Korapuki & 18 & $\begin{array}{l}\text { Wildlife } \\
\text { Sanctuary } \\
\text { (Nature } \\
\text { Reserve) }\end{array}$ & 1986 & Kiore & Rabbits & $\begin{array}{l}\text { Ground-based: kibbled maize in } \\
\text { silos; prefeed followed by maize dosed } \\
\text { with bromodialone }(0.005 \% \text { by wt })\end{array}$ & $\begin{array}{l}\text { McFadden \& } \\
\text { Towns (1991) }\end{array}$ \\
\hline Double & $\begin{array}{l}8 \text { (West) } \\
+19 \text { (East) }\end{array}$ & $\begin{array}{l}\text { Nature } \\
\text { Reserve }\end{array}$ & 1989 & Kiore & None & $\begin{array}{l}\text { Ground-based: kibbled maize in silos; } \\
\text { prefeed with aniseed added followed } \\
\text { by maize dosed with bromodialone } \\
(0.005 \% \text { by wt }) \text { on West Double. } \\
\text { Hand broadcast } 4 \mathrm{~g} \text { pellets of STORM } \\
\text { containing flocoumafen }(0.005 \% \text { by wt }) \\
\text { at } 18.5 \mathrm{~kg} / \mathrm{ha} \text { on East Double }\end{array}$ & $\begin{array}{l}\text { McFadden } \\
\text { (1992) }\end{array}$ \\
\hline Stanley & 100 & $\begin{array}{l}\text { Nature } \\
\text { Reserve }\end{array}$ & 1991 & Kiore & Rabbits & $\begin{array}{l}\text { Aerial spread by helicopter using } \\
\text { modified monsoon bucket; } 0.8 \mathrm{~g} \text { cereal } \\
\text { pellets of TALON } 20 \mathrm{P} \text { containing } \\
\text { brodifacoum at } 20 \mathrm{ppm} \text { with follow-up } \\
\text { hand spread of TALON } 50 \mathrm{WB} \\
\text { (wax blocks) containing brodifacoum at } \\
50 \mathrm{ppm} \text {; total of } 17 \mathrm{~kg} / \mathrm{ha}\end{array}$ & $\begin{array}{l}\text { Towns et al. } \\
\text { (1993) }\end{array}$ \\
\hline $\begin{array}{l}\text { Red } \\
\text { Mercury }\end{array}$ & 225 & $\begin{array}{l}\text { Nature } \\
\text { Reserve }\end{array}$ & 1992 & Kiore & None & $\begin{array}{l}\text { Aerial spread by helicopter using } \\
\text { modified monsoon bucket; TALON } 20 \\
\text { P with follow-up hand spread of } \\
\text { TALON 50WB; } 15 \mathrm{~kg} / \mathrm{ha}\end{array}$ & $\begin{array}{l}\text { Towns et al. } \\
\text { (1994) }\end{array}$ \\
\hline $\begin{array}{l}\text { Middle } \\
\text { Chain }\end{array}$ & 23 & $\begin{array}{l}\text { Nature } \\
\text { Reserve }\end{array}$ & 1992 & Kiore & None & $\begin{array}{l}\text { Aerial spread of TALON } 20 \text { P by } \\
\text { helicopter using modified monsoon } \\
\text { bucket; } 15 \mathrm{~kg} / \mathrm{ha}\end{array}$ & \\
\hline Cuvier & 170 & $\begin{array}{l}\text { Nature } \\
\text { Reserve }\end{array}$ & 1993 & Kiore & None & $\begin{array}{l}\text { Aerial spread of TALON } 20 \mathrm{P} \text { by } \\
\text { helicopter using bait spreader; } 15 \mathrm{~kg} / \mathrm{ha}\end{array}$ & $\begin{array}{l}\text { Towns et al. } \\
\text { (1995) }\end{array}$ \\
\hline Ohinau & 43 & $\begin{array}{l}\text { Iwi (Ngati } \\
\text { Hei) }\end{array}$ & 2005 & $\begin{array}{l}\text { Kiore, } \\
\text { mice }\end{array}$ & Rabbits & $\begin{array}{l}\text { Aerial spread of PESTOFF 20R } \\
\text { containing brodifacoum in two } \\
\text { operations by helicopter using bait } \\
\text { spreader; } 8+8 \mathrm{~kg} / \mathrm{ha}\end{array}$ & $\begin{array}{l}\text { R Chappell } \\
\text { (pers. comm.) }\end{array}$ \\
\hline $\begin{array}{l}\text { Great } \\
\text { Mercury }\end{array}$ & 1872 & Private & 2014 & $\begin{array}{l}\text { Kiore, } \\
\text { ship rats }\end{array}$ & Goats, cats & $\begin{array}{l}\text { Aerial spread of PESTOFF 20R } \\
\text { containing brodifacoum in two } \\
\text { operations by helicopter using bait } \\
\text { spreader; } 8.8+13.2 \mathrm{~kg} / \mathrm{ha}\end{array}$ & $\begin{array}{l}\text { P Corson } \\
\text { (pers. comm.) }\end{array}$ \\
\hline
\end{tabular}

\section{References}

McEwen WM 1987. Ecological regions and districts of New Zealand. Wellington, Department of Conservation. $63 \mathrm{p}$.

McFadden I 1992. Eradication of kiore (Rattus exulans) from Double Island, Mercury Group in Northern New Zealand. Science and Research Internal Report No. 130. Wellington, Department of Conservation. $12 \mathrm{p}$.

McFadden I, Towns D 1991. Eradication campaigns against kiore (Rattus exulans) on Rurima Rocks and Korapuki Island, northern New Zealand. Science and Research Internal Report No. 97. Wellington, Department of Conservation. $18 \mathrm{p}$.

Towns DR, Broome KG 2003. From small Maria to massive Campbell: forty years of rat eradications from New Zealand islands. New Zealand Journal of Zoology 30: 377-398.

Towns D, McFadden I, Lovegrove T 1993. Offshore islands co-operative conservation project with ICI Crop Care Division: Phase One (Stanley Island). Science and Research Internal Report No. 138. Wellington, Department of Conservation. $24 \mathrm{p}$.

Towns D, McFadden I, Thomson P, Robertson H, Colbourne R 1994. Offshore islands co-operative conservation project with ICI Crop Care Division: Phase Two (Red Mercury Island). Science and Research Internal Report No. 142. Wellington, Department of Conservation. $12 \mathrm{p}$.

Towns D, McFadden I, Thomson P 1995. Offshore islands co-operative conservation project with ICI Crop Care Division: Phase Three (Cuvier Island). Science and Research Internal Report No. 150. Wellington, Department of Conservation. $13 \mathrm{p}$. 